\title{
TESTING WAGNER'S LAW AND KEYNESIAN HYPOTHESIS IN SELECTED POST-SOVIET COUNTRIES
}

\author{
Jeyhun A. Abbasov ${ }^{1,2,3}$, Khatai Aliyevev, 5,6 \\ ${ }^{1}$ Central Bank of Azerbaijan Republic, AZ1014, Rashid Behbudov str. 90, Baku, Azerbaijan \\ ${ }^{2}$ Azerbaijan State University of Economics, International Graduate and Doctorate Center, AZ1001, Istiqlaliyyat \\ str. 6, Baku, Azerbaijan \\ ${ }^{3}$ Baku Engineering University, Department of Mathematics and Informatics, AZ0101, Hasan Aliyev str. 120, \\ Khirdalan city, Azerbaijan \\ ${ }^{4}$ Azerbaijan State University of Economics, UNEC Empirical Research Center, AZ1001, Istiqlaliyyat str. 6, Baku, \\ Azerbaijan \\ ${ }^{5}$ Baku Engineering University, Department of World Economy, AZ0101, Hasan Aliyev str. 120, Khirdalan city, \\ Azerbaijan \\ ${ }^{6}$ ASERC LLC, AZ1110, Mirali Gashgai str. 97/37, Baku, Azerbaijan
}

To cite this article: ABBASOV JEYHUN A., ALIYEV KHATAI. 2018. Testing Wagner's Law and Keynesian Hypothesis in Selected Post-Soviet Countries. Acta Universitatis Agriculturae et Silviculturae Mendelianae Brunensis, 66(5): 1227-1237.

To link to this article: https://doi.org/10.11118/actaun201866051227

\begin{abstract}
The aim of this research is to test Wagner's law and Keynesian hypothesis in 9 Post-Soviet countries - Estonia, Latvia, Lithuania, Uzbekistan, Azerbaijan, Georgia, Kyrgyz Republic, Moldova, and Ukraine. For this purpose, long- and short-run causality between real per capita GDP and real per capita government expenditures are estimated by employing ARDL modelling approach. Estimation results support validity of Wagner's law for Latvia, Lithuania, Uzbekistan, Georgia, Kyrgyz Republic and Ukraine, and validity of Keynesian hypothesis for Estonia, Uzbekistan, Azerbaijan, Kyrgyz Republic, and Moldova in the long-run. Meanwhile, research findings indicate strong bidirectional short-run causality in all countries except Lithuania and Kyrgyz Republic in the short-run.
\end{abstract}

Keywords: Wagner's law; Keynesian Hypothesis; Post-Soviet countries; long-run association; short-run causality; ARDL modeling approach

\section{INTRODUCTION}

Recently, the definition of the casual relationship between economic activity and government spending takes priority over other issues in government's fiscal policy and central bank's monetary policy. Moreover, the casual relationship between these two macroeconomic indicators is of great interest among economists in macroeconomic research. The Wagner's (1890) law and the Keynesian (1936) hypothesis are two different theoretical frameworks on the causal relationship between government spending and national income or economic activity. Before Wagner, classical economists argued that government expenditures have adverse impact on the economic growth. In contrast, both the Wagner's law and the Keynesian hypothesis support existence of positive long-run association between public spending and economic activity. However, Wagner's law gives a theoretical hypothesis for the direction of causation from economic activity to government spending $(\mathrm{Y} \rightarrow \mathrm{X})$ while the Keynesian hypothesis argues that government expenditure affects economic activity $(\mathrm{X} \rightarrow \mathrm{Y})$. 
The association between public spending and national income has been subject to a lot of empirical studies end with distinct and sometimes even conflicting results. According to Nijikamp and Poot (2004) who has reviewed results of 41 empirical researches devoted to long-run association of interest, $17 \%$ conclude with the existence of positive and $29 \%$ negative association while in $54 \%$ of those studies, the research output does not reveal any significant association. Afterwards, still empirical findings display differences depend on the case of research, the period taken, and econometric methodology employed. For example, Taban (2010) has found negative long-run causality between public expenditures and economic growth for Turkey. For the case of Nigeria, Ighodaro and Okiakhi (2010) reveals negative association while Igve et al. (2015) conclude with positive relationship between the variables of interest. The issue is still remains its attractiveness in latest empirical literature (see Quy, 2017; Pascual Sáez et al., 2017; Chan et al., 2017; Lupu and Asandului, 2017; Aliyev et al., 2016; Dehning et al., 2016; Aliyev and Nadirov, 2016; Kargi, 2016; Aliyev and Mikayilov, 2016; Atasoy and Gur, 2016; Merza and Alhasan, 2016; Magazzino et al., 2015; Afonso and Jalles, 2014; Alshahrani and Alsadiq, 2014; Dogo et al., 2013; Bashirli and Sabiroglu, 2013, among others).

Economic activity is an aggregate index that affects the financial position of the people, as well as directly characterizes the level of economic development of the country. On the other hand, government expenditures contribute to the creation of income in the private sector through multiplier effects which was determined by Keynes (1936). From this point of view, the change in government spending can certainly affect an overall per capita GDP. In some cases, income or GDP have causal effects on government expenditures which is so called as Wagner's (1890) law. Whereas, for some countries, both Keynesian (1936) hypothesis and Wagner's (1890) law are accepted on the base of results of corresponding researches.

This research analyzes the causal relationship between economic activity and government expenditure in selected Post-Soviet Countries - Azerbaijan, Belarus, Estonia, Georgia, Lithuania, Moldova and Ukraine. Data set is on the base of quarterly for Azerbaijan (2005Q1-2017Q3), Estonia, Latvia and Lithuania (2000Q1-2017Q3), while is at yearly frequency for Uzbekistan (1992-2017), Georgia, Kyrgyz, Moldova and Ukraine (1995-2017), individually.

\section{MATERIALS AND METHODS}

In the current literature, representation of public expenditure as well as economic activity is different while Keynesian hypothesis and Wagner law are tested. Tab. I overview used proxies for public expenditure and economic activity in some of such studies.

Considering data availability issue, association between real government expenditure and real GDP

I: Representation of public expenditure and economic activity

\begin{tabular}{|c|c|c|}
\hline Public expenditure is represented by & Economic activity is represented by & Research work \\
\hline Real government spending & Real non-oil GDP & $\begin{array}{l}\text { Aliyev et el., (2016); Dehning et al., } \\
\text { (2016); Hasanov et al., (2018) }\end{array}$ \\
\hline Government budget expenditures & Total GDP & Bashirli and Sabiroglu (2013) \\
\hline Total budget expenditure & GDP growth & Quy (2017) \\
\hline General government expenditure & Total GDP & Magazzino et al., (2015) \\
\hline Real public spending & Real GDP / per capita GDP & Ağayev (2012) \\
\hline Real government spending & Real GNP & Peacock and Wiseman (1961) \\
\hline $\begin{array}{l}\text { Real per capita government } \\
\text { expenditure }\end{array}$ & Real per capita national income & Singh and Sahni (1984) \\
\hline $\begin{array}{l}\text { The first difference of the logarithm of } \\
\text { real per capita government expenditure }\end{array}$ & $\begin{array}{l}\text { The first difference of the logarithm } \\
\text { of real per capita GDP }\end{array}$ & Katrakilidis and Tsaliki (2009) \\
\hline $\begin{array}{l}\text { The share of real government spending } \\
\text { in real GNP }\end{array}$ & Real GNP & $\operatorname{Man}(1980)$ \\
\hline $\begin{array}{l}\text { Per capita nominal government } \\
\text { expenditure }\end{array}$ & Per capita nominal national income & Holmes and Hutton (1990) \\
\hline $\begin{array}{l}\text { Real per capita government } \\
\text { expenditure }\end{array}$ & Real per capita national income & Ahsan et al. (1992) \\
\hline $\begin{array}{l}\text { The annual growth rate of real per } \\
\text { capita government spending }\end{array}$ & $\begin{array}{l}\text { The annual growth rate of real per } \\
\text { capita gross domestic income }\end{array}$ & Landau (1985) \\
\hline $\begin{array}{l}\text { The natural logarithm of general } \\
\text { government expenditure }\end{array}$ & $\begin{array}{l}\text { The natural logarithm of aggregate } \\
\text { GDP }\end{array}$ & $\operatorname{Ram}(1987)$ \\
\hline
\end{tabular}

Source: authors' own completion. 
is examined within dynamic time-series analysis framework. For all models, elasticity models are estimated, i.e., both variables are taken as natural logarithm. For better representation, $Y$ and $X$ letters are used for real GDP, and the real government expenditure, respectively. Data is retrieved from Eurostat database which covers the period of 2000Q1-2017Q3 at constant prices for Estonia, Lithuania and Latvia, the State Statistical Committee of the Republic of Azerbaijan and The Ministry of Finance of the Republic of Azerbaijan and IMF. Graphical trends of model variables for all countries are given in the Appendix A. Note that, these graphs will be discussed with the results of ADF unit root test with breakpoints in the next section.

\section{Methods}

Granger's (1969) causality test is the traditional econometric technique to test the causal relationship between the variables. So, we can apply the test to examine the association between per capita GDP and per capita government expenditure in selected Post-Soviet Countries. But, there is one important point in running the Granger causality test. This test requires the variables to be stationary time series (see Granger, 1969, p. 426). As usual, time-series data is non-stationary, because of the presence of trend factor. We know that the standard regression estimation can become irrelevant if the variables are non-stationary. It means that estimated regression coefficients suggest only spurious information about the correlation between the variables. To avoid this problem, all non-stationary variables can be decomposed into the trend and stationary components by using HP filter (or by using some other filters) or we can convert these non-stationary variables to stationary variables by taking their first difference. But, in this case, we can only investigate the short-run causal association. Nevertheless, the main purpose of this research is to test the long-run causal relationship (Wagner's law and the Keynesian hypothesis) between the real per capita GDP and the real per capita government expenditure,

Autoregressive Distributed Lag (ARDL) technique (it is also known as Bound Test) suggested by Pesaran and Shin (1999) and Pesaran et al. (2001) perform better than alternatives. Firstly, ARDL allows to estimate short-run and long-run causal associations between variables, simultaneously, regardless if the variables are $\mathrm{I}(0), \mathrm{I}(\mathrm{l})$ or combination of both. Meanwhile, because lags of both dependent and explanatory variables are included to the estimations, endogeneity issue is mostly controlled.

The technique is consisted of the following stages: (1) construction of an unrestricted ECM, (2) testing existence of cointegrating relationship or long-run association by using Wald-test (or the F-Test), (3) calculating the long-run coefficients by applying Bewley (1979) transformation if existence of cointegrating relationship among the variables is approved, (4) calculating long-run residuals and re-estimating the model by substituting long-run regressors by one lagged residuals. Detailed description of the estimation procedure is available in Pesaran et al. (2001) as well as Hasanov et al. (2016).

Error Correction Model (hereafter ECM) structure for ARDL is given below:

$\Delta y_{t}=\alpha_{0}+\beta_{1} y_{t-1}+\beta_{2} x_{t-1}+\sum_{i=1}^{n} \gamma_{i} * \Delta y_{t-i}+\sum_{i=1}^{m} \varphi_{i} * \Delta x_{t-i}+u_{t}$

And

$\Delta x_{t}=\delta_{0}+\theta_{1} x_{t-1}+\theta_{2} y_{t-1}+\sum_{i=1}^{l} \rho_{i} * \Delta x_{t-i}+\sum_{i=1}^{k} \mu_{i} * \Delta y_{t-i}+\vartheta_{t}$

Where $y$ and $x$ represent real per capita GDP, and the real per capita government expenditure. $\alpha_{0}$ and $\delta_{0}$ denote drift coefficients. $\beta_{0}$ and $\beta_{2}$ as well as $\theta_{0}$ and $\Theta_{2}$ are long-run coefficients. Short-run coefficients are $\gamma_{1}, \varphi_{i}, \rho_{1}$, and $\mu_{i}$ where $n, m$, l, and $k$ indicate lag size, $u$ and $\vartheta$ are white noise errors. $t$ denotes the time.

Note that the validity of critical values of F-distribution for small and large samples are disputable and there are various approaches. The critical values calculated by Pesaran and Pesaran (1997) obtained from large sample sizes. Narayan (2005) argues that those critical values are not highly accurate in case of small sample sizes. Calculations show that Narayan's (2005) critical values for relatively small number of observation is larger than those of Pesaran and Pesaran (1997). To get more accurate results, we will use both critical values while testing existence of long run association in ARDL models.

\section{RESULTS}

Before estimating ARDL model specifications, we should determine order of integration of variables by Augmented Dickey-Fuller (hereafter ADF) unit root test is employed (see Dickey and Fuller, 1979; Dickey and Fuller, 1981) for all countries covered. By employing ADF unit root test, stationarity of model variables will be tested with intercept as well as with trend and intercept. But, Fig. Al and Fig. A2 let us to suspect the structural breaks for most of the studied countries. When there are structural breaks, ADF test statistics are biased towards the nonrejection of a unit root (see Enders (2004), p. 200). To avoid this problem, we used unit root test with breakpoints by using Eviews 9.

The results, reported in Tab. II, confirm that both real government spending and real GDP have I(1) process with intercept for all countries while have both $\mathrm{I}(0)$ process and $\mathrm{I}(\mathrm{l})$ process with intercept and trend for some countries identifying some possible break points. According to Tab. II, the real GDP is $\mathrm{I}(0)$ or I(1) for Estonia, Moldova and Uzbekistan only when trend is included while is I(1) for Georgia only when trend is not included.

In the same way, real government expenditure is $\mathrm{I}(0)$ and $\mathrm{I}(1)$ at $5 \%$ level of significance with intercept 
II: The results of ADF unit root test with breakpoints

\begin{tabular}{|c|c|c|c|c|c|c|c|c|c|}
\hline \multirow[b]{2}{*}{ Variables } & \multirow[b]{2}{*}{ Countries } & \multicolumn{4}{|c|}{ with intercept } & \multicolumn{4}{|c|}{ with intercept and trend } \\
\hline & & $\mathbf{I}(0)$ & $\begin{array}{l}\text { Break } \\
\text { point }\end{array}$ & $\mathbf{I}(1)$ & $\begin{array}{l}\text { Break } \\
\text { point }\end{array}$ & $\mathbf{I}(0)$ & $\begin{array}{l}\text { Break } \\
\text { point }\end{array}$ & $\mathbf{I}(1)$ & $\begin{array}{l}\text { Break } \\
\text { point }\end{array}$ \\
\hline \multirow{9}{*}{$\ln (Y)$} & Azerbaijan & -1.80 & 2009Q4 & $-4.67^{* *}$ & 2009Q3 & -3.57 & 2015Q3 & $-4.64^{*}$ & 2009Q3 \\
\hline & Estonia & -0.78 & 2007Q2 & -3.62 & 2007Q1 & $-4.80^{* *}$ & 2008Q3 & -4.03 & 2007Q2 \\
\hline & Georgia & 1.01 & 2008 & $-5.25^{* * *}$ & 2007 & -3.76 & 2014 & -3.32 & 2008 \\
\hline & Lithuania & 0.39 & 2008Q1 & $-6.97^{* * *}$ & 2007Q4 & $-4.70^{* *}$ & 2008Q4 & $-7.43^{* * *}$ & 2007Q4 \\
\hline & Latvia & 0.52 & 2007Q4 & $-5.22^{* * *}$ & 2007Q3 & -1.42 & 2007Q3 & $-6.99^{* * *}$ & 2007Q3 \\
\hline & Moldova & 0.83 & 2014 & -1.69 & 2006 & $-4.63^{*}$ & 2015 & $-4.38^{*}$ & 2007 \\
\hline & Kyrgyz & -0.41 & 2009 & $-5.19^{* * *}$ & 2009 & $-5.34^{* *}$ & 2011 & $-5.04^{* *}$ & 2009 \\
\hline & Uzbekistan & -0.31 & - & -2.24 & - & $-3.81^{* *}$ & - & -1.48 & - \\
\hline & Ukraine & -0.85 & 2015 & $-4.47^{* * *}$ & 2009 & -1.93 & 2014 & $-3.97^{*}$ & 2009 \\
\hline \multirow{9}{*}{$\ln (X)$} & Azerbaijan & -2.50 & 2015Q2 & $-7.74^{* * *}$ & 2009Q2 & -3.75 & 2015Q2 & $-7.64^{* * *}$ & 2009Q2 \\
\hline & Estonia & 0.61 & 2006Q3 & $-7.42^{* * *}$ & 2006Q3 & -3.52 & 2007Q2 & $-5.00^{* *}$ & 2007Q2 \\
\hline & Georgia & 2.19 & 2008 & -3.55 & 2007 & $-5.06^{* *}$ & 2014 & -4.17 & 2009 \\
\hline & Lithuania & 1.55 & 2009Q1 & $-7.17^{* * *}$ & 2008Q4 & 0.89 & 2009Q1 & $-6.70^{* * *}$ & 2009Q1 \\
\hline & Latvia & 0.94 & 2009Q2 & -3.24 & 2009Q2 & -1.99 & 2009Q2 & $-4.73^{* *}$ & 2009Q2 \\
\hline & Moldova & 0.07 & 2008 & $-4.63^{* *}$ & 2008 & $-8.80^{* * *}$ & 2014 & $-4.43^{*}$ & 2008 \\
\hline & Kyrgyz & 1.25 & 2013 & $-5.83^{* * *}$ & 2012 & -3.23 & 2002 & $-4.88^{* *}$ & 2014 \\
\hline & Uzbekistan & 1.14 & 2014 & $-9.85^{* * *}$ & 2015 & $-4.60^{*}$ & 2000 & -0.38 & 2010 \\
\hline & Ukraine & -1.01 & 2015 & $-5.07^{* * *}$ & 2009 & -3.13 & 2014 & $-5.21^{* * *}$ & 2009 \\
\hline
\end{tabular}

Note: $\mathbf{Y}$ - real per capita GDP; $\boldsymbol{X}$ - real per capita government expenditure; $\boldsymbol{l n}$ - natural logarithm; ***, **, and *denote significance levels at $1 \%, 5 \%$, and $10 \%$, remaining values are insignificant. Structure of the testing equation has been chosen automatically using AIC

and trend for Georgia and Latvia, respectively. This variable is $\mathrm{I}(\mathrm{I})$ or $\mathrm{I}(0)$ with intercept or with intercept and trend at $5 \%$ and more significant levels for remaining countries.

The breakpoints in Tab. II which have been revealed by unit root test with breakpoints are mostly consistent with the 2007-08 financial crisis and the oil price shock of 2014. According to ADF unit root test results, model variables are $\mathrm{I}(0)$ or $\mathrm{I}(\mathrm{I})$ for all selected Post-Soviet countries. Therefore, ARDL methodology is applicable for all countries and we can proceed with description of estimation process, and interpretation of results.

Next stage is to select optimal lag size. To determine optimal lag sizes, the lowest values of AIC is taken as a decision criteria for each corresponding ARDL model. Including trend or not is decided according to unit root test results (see Tab. II).

Beyond having minimum AIC value, residuals of the selected ARDL models must be normally distributed, homoscedastic, no serially correlated and stable. Therefore, before the co-integration diagnostic, we must check these assumptions for all ARDL models. In this context, Jarque-Bera test for normality (see Jarque and Bera, 1987), Breusch-Pagan-Godfrey test for homoscedasticity (see Breusch and Pagan, 1979), Breusch-Godfrey LM Test for serial correlation (see Breusch, 1978; Godfrey, 1978), and CUSUM (cumulative sum) test (see Page, 1954) for the analysis of stability.
Because our analysis covers 9 Post-Soviet countries and different ARDL models are specified to estimate, it is difficult to present all estimation results. To conserve the space of main text, only estimation results of selected models with optimal lag size as well as residual diagnostics and stability test outputs are given in Tab. III and Tab. IV, respectively. According to the residual diagnostics test results, estimated models have no serial correlation or heteroscedasticity problems at 5\% level of significance. In a number of models, it is revealed that residuals are not normally distributed. However, there is stability in all models (see Appendix B). Therefore, we conclude that estimated fulfills required conditions.

Next stage is to test for long-run association or existence of cointegration as well as short run causality in estimated models. In other words, validity of Wagner's law and Keynes's hypothesis will be examined for each selected Post-Soviet countries, individually. Long-run and short-run causality test results are reported in in Tab. III and Tab. IV.

For better understanding of research findings, the conclusion of estimation results are tabulated in Tab.V. Note that this conclusion refers to Tab. III and IV. Research findings provides significant evidence about the validity of both Wagner's Law and Keynesian Hypothesis in the short-run for Estonia, Latvia, Uzbekistan, Azerbaijan, Georgia, Moldova, and Ukraine. In case of Lithuania, no 


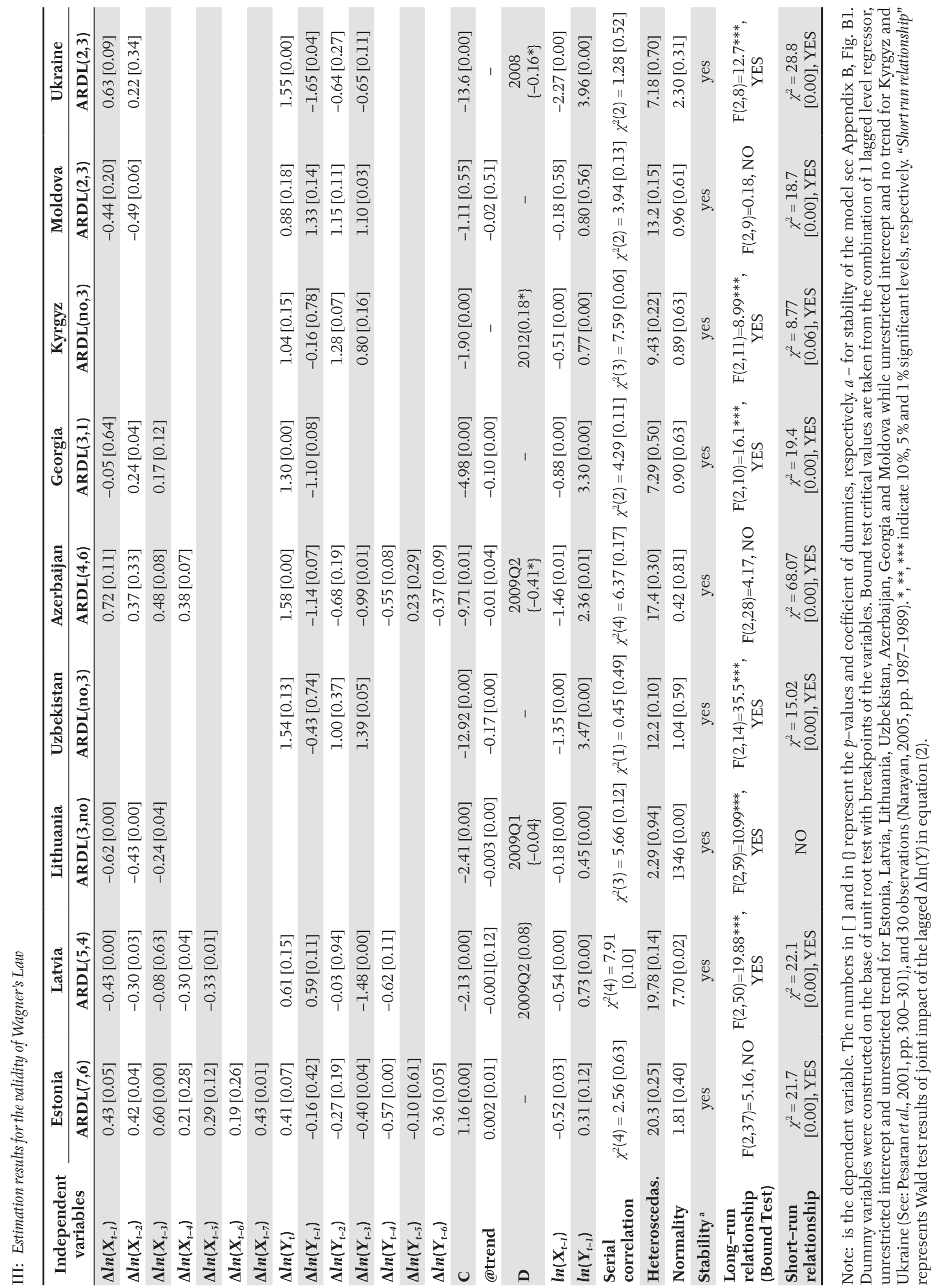




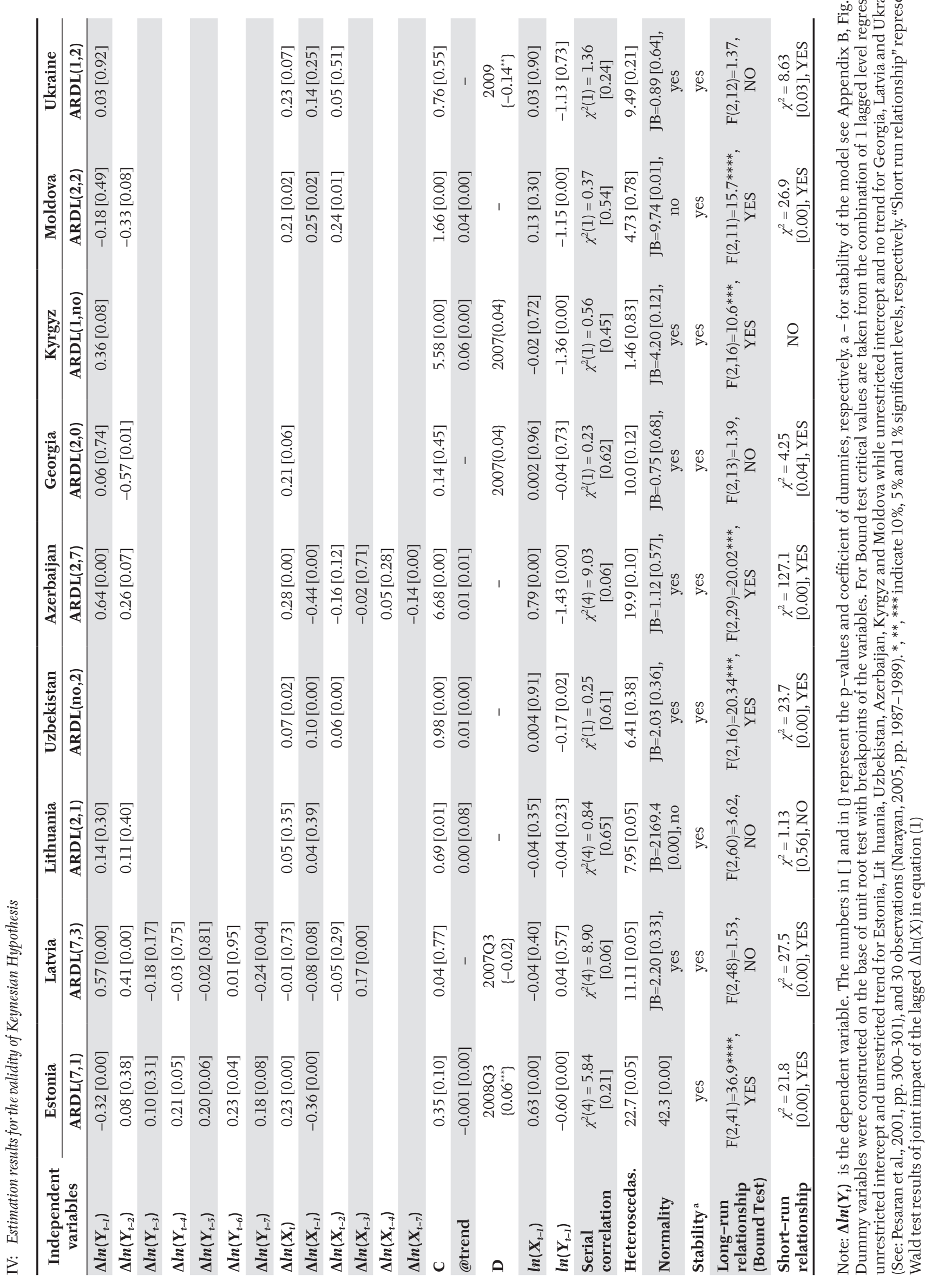


V: The directions of the short-run and the long-run causality

\begin{tabular}{|c|c|c|}
\hline Country & Short-run causality & Long-run causality \\
\hline Estonia & $\mathrm{Y} \leftrightarrow \mathrm{X}$ & $X \rightarrow Y$ \\
\hline Latvia & $\mathrm{Y} \leftrightarrow \mathrm{X}$ & $\mathrm{Y} \rightarrow \mathrm{X}$ \\
\hline Lithuania & NO & $\mathrm{Y} \rightarrow \mathrm{X}$ \\
\hline Uzbekistan & $\mathrm{Y} \leftrightarrow \mathrm{X}$ & $\mathrm{Y} \leftrightarrow \mathrm{X}$ \\
\hline Azerbaijan & $\mathrm{Y} \leftrightarrow \mathrm{X}$ & $\mathrm{X} \rightarrow \mathrm{Y}$ \\
\hline Kyrgyz & $\mathrm{Y} \rightarrow \mathrm{X}$ & $\mathrm{Y} \leftrightarrow \mathrm{X}$ \\
\hline Moldova & $\mathrm{Y} \leftrightarrow \mathrm{X}$ & $\mathrm{X} \rightarrow \mathrm{Y}$ \\
\hline Ukraine & $\mathrm{Y} \leftrightarrow \mathrm{X}$ & $\mathrm{Y} \rightarrow \mathrm{X}$ \\
\hline
\end{tabular}

Note: $\mathbf{Y}$ - real per capita GDP; $\boldsymbol{X}$ real per capita government expenditure; "No" means no long-run causality between X and Y (see Tab. III and Tab. IV). „ $\rightarrow$ " and „↔" denote unidirectional causality and bidirectional causality, respectively.

significant short-run causality is detected. There is unidirectional short-run association in case of Kyrgyz Republic-validity of Wagner's Law is confirmed.

In long-term perspective, validity of both Wagner's law and Keynesian Hypothesis only in two countries: Uzbekistan, and Kyrgyz Republic. In Estonia, Azerbaijan, and Moldova, validity of only Keynesian Hypothesis is supported. However, only Wagner's law is found to be valid in case of Latvia, Lithuania, Georgia, and Ukraine.

\section{DISCUSSION AND CONCLUSION}

The association between economic growth performance and government expenditures is one of the major issues that policy-makers should take into consideration. The relationship is expected to be bidirectional when Wagner's law (Wagner, 1890) and Keynesian hypothesis (Keynes, 1936) frameworks are taken into consideration. From policy-making point of view, both directions of the relationship are important to be studied as Wagner's law warns policymakers to carefully plan the amount of government expenditures in response to expectations of economic agents. Meanwhile, within the Keynesian framework, the multiplier effect of government expenditures should be measured to stimulate economic growth again to satisfy the expectations of economic agents. So, this issue is always open to new empirical investigations. In this research, the association is examined by using real per capita data instead of total amount of GDP and government expenditures.

This research targets to test both Wagner's law and Keynesian hypothesis in the case of 9 Post Soviet countries, namely Estonia, Latvia, Lithuania, Uzbekistan, Azerbaijan, Georgia, Kyrgyz Republic, Moldova, and Ukraine. Note that Soviet Union collapsed in 1991 and these countries declared their independence. That is why the research covers the period after 1991. By employing ARDL techniques applied to time-series data, long- and short-run association between real per capita GDP and real per capita government expenditures are examined.

Estimation results reveal validity of Wagner's Law and Keynesian Hypothesis in all selected countries except Lithuania, and Kyrgyz Republic in the short-run. For Kyrgyz Republic, only Wagner's Law is valid while neither for Lithuania. In the long-run, it is defined that Wagner's law is valid for Latvia, Lithuania, Uzbekistan, Georgia, Kyrgyz Republic, and Ukraine while empirical findings support validity of Keynesian hypothesis for Estonia, Uzbekistan, Azerbaijan, Kyrgyz Republic, and Moldova.

Research findings support the outcome existence of previous studies at some level. For Azerbaijan, Wagner's law is found to be valid in Bashirli and Sabiroglu (2013) while here it is not. However, existing studies mostly support existence of Keynesian hypothesis (see Aliyev et al., 2016; Dehning et al., 2016; Aliyev and Nadirov, 2016; Aliyev and Mikayilov, 2016; Hasanov et al., 2018 among others). Magazzino et al. (2015) reveals validity of both in case of Estonia and non for Latvia and Lithuania. Abdiyeva and Çetintaş (2017) provide scientific evidence about validity of Wagner's law in Kyrgyz Republic. The cause of variation in results can be due to the differences in investigation period as well as the methods employed for empirical estimations.

\section{REFERENCES}

ABDIYEVA, R. and ÇETINTAŞ, H. 2017. Kamu Harcamaları ve Ekonomik Büyüme Arasındaki ĠliG̣ki: Kırgızistan Örneği. Optimum: Journal of Economics $\sigma$ Management Sciences/Ekonomi ve Yönetim Bilimleri Dergisi, 4(1): 19-34.

AFONSO, A. and JALLES, J. T., 2014. Causality for the government budget and economic growth. Applied Economics Letters, 21(17): 1198-1201. 
AHSAN, S. M., KWAN, A. C. and SAHNI, B. S. 1992. Public expenditure and national income causality: further evidence on the role of omitted variables. Southern Economic Journal, 58(3): 623-634.

AĞAYEV, S. 2012. Kamu harcamaları ve ekonomik büyüme ilişkisi: eski Sovyetler birliği ülkelerinde Wagner yasası analizi (1995-2009). Eskişehir Osmangazi Üniversitesi İktisadi ve İdari Bilimler Dergisi, 7(2): 7-27.

ALIYEV, K., DEHNING, B. and NADIROV, O. 2016. Modelling the impact of fiscal policy on nonoil GDP in a resource rich country: evidence from Azerbaijan. Acta Universitatis Agriculturae et Silviculturae Mendelianae Brunensis, 64(6): 1869-1878.

ALIYEV, K. and NADIROV, O. 2016. How fiscal policy affects non-oil economic performance in Azerbaijan? Academic Journal of Economic Studies, 2(3): 11-29.

ALIYEV, K. and MIKAYILOV, C. 2016. Does the budget expenditure composition matter for long-run economic growth in a resource rich country? Evidence from Azerbaijan. Academic Journal of Economic Studies, 2(2): 147-168.

ALSHAHRANI, M. S. A. and ALSADIQ, M. A. J. 2014. Economic growth and government spending in Saudi Arabia: An empirical investigation. International Monetary Fund.

ATASOY, B. S. and GÜR, T. H. 2016. Does the Wagner's hypothesis hold for china? Evidence from static and dynamic analyses. Panoeconomicus, 63(1): 45-60.

BASHIRLI, S. and SABIROGLU, I. M. 2013. Testing Wagner's Law in an oil-exporting economy: The case of Azerbaijan. Transition Studies Review, 20(3): 295-307.

BEWLEY, R. A., 1979. The direct estimation of the equilibrium response in a linear dynamic model. Economics Letters, 3(4): 357-361.

BREUSCH, T. S., 1978. Testing for autocorrelation in dynamic linear models. Australian Economic Papers, 17(31): 334-355.

BREUSCH, T. S. and PAGAN, A. R., 1979. A simple test for heteroscedasticity and random coefficient variation. Econometrica: Journal of the Econometric Society, 47(5): 1287-1294.

CHAN, S. G., RAMLY, Z. and KARIM, M. Z. A. 2017. Government Spending Efficiency on Economic Growth: Roles of Value-added Tax. Global Economic Review, 46(2): 162-188.

DICKEY, D. A. and FULLER, W. A., 1979. Distribution of the estimators for autoregressive time series with a unit root. Journal of the American statistical association, 74(366a): 427-431.

DICKEY, D. A. and FULLER, W. A., 1981. Likelihood ratio statistics for autoregressive time series with a unit root. Econometrica: Journal of the Econometric Society, 49(4): 1057-1072.

DOGO, M. Y., OKPANACHI, U. M., MUHAMMAD, A. A., UMOLU, C. V. and AJAYI, K. J. 2013. Government Size and Economic Growth in Nigeria: A Test of Wagner's Hypothesis. Economic and Financial Review, 51(3): 57-88.

GODFREY, L. G. 1978. Testing against general autoregressive and moving average error models when the regressors include lagged dependent variables. Econometrica: Journal of the Econometric Society, 46(6): 1293-1301.

GRANGER, C. W., 1969. Investigating causal relations by econometric models and cross-spectral methods. Econometrica: Journal of the Econometric Society, 37(3): 424-438.

HASANOV, F., MIKAYILOV, C., YUSIFOV, S. and ALIYEV, K., 2016. Impact of Fiscal Decentralization on Non-Oil Economic Growth in a Resource-Rich Economy. Eurasian Journal of Business and Economics, 9(17): 87-108.

HASANOV, F., MAMMADOV, F. and AL-MUSEHEL, N. 2018. The Effects of Fiscal Policy on Non-Oil Economic Growth. Economies, 6(2): 27.

HOLMES, J. M. and HUTTON, P. A. 1990. On the casual relationship between government expenditures and national income. The Review of Economics and Statistics, 72(1): 87-95.

IGHODARO, C. A. and ORIAKHI, D. E. 2010. Does the relationship between government expenditure and economic growth follow Wagneres s law in Nigeria. Annals of University of Petrosani Economics, 10(2): 185-198.

IGWE, A., EMMANUEL, E. C. and UKPERE, W. I. 2015. Impact of fiscal policy variables on economic growth in Nigeria (1970-2012): A managerial economics perspective. Investment Management and Financial Innovations, 12(2): 169-179.

JARQUE,C.M.andBERA,A.K.1987.A testfornormality of observations and regression residuals. International Statistical Review/Revue Internationale de Statistique, 55(2): 163-172.

KARGI,B.2016.Is Wagner's law applicableforfast growing economies? BRICS and MATIKcountries. Timisoara Journal of Economics and Business, 9(1):1-15.

KATRAKILIDIS, C. and TSALIKI, P. 2009. Further evidence on the causal relationship between government spending and economic growth: The case of Greece, 1958-2004. Acta Oeconomica, 59(1): 57-78.

KEYNES, J. M. 1936. General Theory of Employment, Interest and Money. London: Macmillan.

LANDAU, D. L. 1985. Government expenditure and economic growth in the developed countries: 1952-76. Public Choice, 47(3): 459-477.

LUPU, D. and ASANDULUI, M. 2017. The Nexus between Economic Growth and Public Spending in Eastern European Countries. Engineering Economics, 28(2):155-161.

Magazzino, C., Giolli, L. and Mele, M., 2015. Wagner's Law and Peacock and Wiseman's Displacement Effect in European Union Countries: A Panel Data Study. International Journal of Economics and Financial Issues, 5(3): 812-819. 
MANN, A. J. 1980. Wagner's law: An econometric test for Mexico, 1925-1976. National Tax Journal, 33(2): $189-201$. MERZA, E. and ALHASAN, N. 2016. Public Spending and Economic Growth in the Rentier State: The Case of Kuwait. Asian Social Science, 12(8): 160-170.

NARAYAN, P. K. 2005. The saving and investment nexus for China: evidence from cointegration tests. Applied economics, 37(17): 1979-1990.

NIJKAMP, P. and POOT, J. 2004. Meta-analysis of the effect of fiscal policies on long-run growth. European Journal of Political Economy, 20(1): 91-124.

PAGE, E. S. 1954. Continuous inspection schemes. Biometrika, 41(1/2): 100-115.

PASCUAL SÁEZ, M., ALVAREZ-GARCÍA, S. and CASTANEDA, D. 2017. Governmen expenditure and economic growth in the European Union countries: New evidence. In: CHODKOWSKA-MISZCZUK, J. and SZYMAŃSKA, D. (Eds.). Bulletin of Geography. Socio-economic Series, No. 36. Toruń: Nicolaus Copernicus University, pp. 127-133.

PEACOCK, A. T. and WISEMAN, J. 1961. The growth of government expenditures in the United Kingdom. Princeton: Princeton Univercity Press.

PERRON, P. 1989. The Great Crash, the Oil Price Shock, and the Unit Root Hypothesis. Econometrica, 57(6): 1361-1401.

PESARAN, M. H., SHIN, Y. and SMITH, R. J. 2001. Bounds testing approaches to the analysis of level relationships. Journal of applied econometrics, 16(3): 289-326.

PESARAN,H.M., and SHIN, Y. 1999. An Autoregressive Distributed Lag Modeling Approach to Cointegration analysis. In: STROM, S. Econometrics and Economic Theory in the 20th Century: The Ragnar Frisch Centennial Symposium. Cambridge, UK: Cambridge University Press, pp. 371-413.

PESARAN, H. M. and PESARAN, B. 1997. Working with Microfit 4.0: Interactive Econometric Analysis. Oxford University Press, UK.

QUY, N. H. 2017. The Role of Public Expenditures in Economic Growth at Provincial Level: Empirical Study in Vietnam. Journal of Politics and Law, 10(2): 88-96.

RAM, R. 1987. Wagner's hypothesis in time-series and cross-section perspectives: Evidence from" real" data for 115 countries. The review of Economics and Statistics, 69(2): 194-204.

SINGH, B. and SAHNI, B. S. 1984. Causality between public expenditure and national income. The Review of economics and Statistics, 66(4): 630-644.

TABAN, S. 2010. An examination of the government spending and economic growth nexus for Turkey using the bound test approach. International Research Journal of Finance and Economics, 48: 184-193.

VOGELSANG, T. J. and PERRON, P. 1998. Additional Tests for a Unit Root Allowing for a Break in the Trend Function at an Unknown Time. International Economic Review, 39(4): 1073-1100.

WAGNER, A. 1890. Finanzwissenschaft. Zweiter Theil: Theorie der Besteuerung, Gebuhrenlehre und allgemeine Steuerlehre. 2. Aufl., Leipzig: C.F. Winter.

ENDERS, W. 2004. Applied Econometric Time Series. $2^{\text {nd }}$ Edition. Wiley series in probability and statistics. Wiley \& Sons, Inc.

ZIVOT, E. and ANDREWS, D. W. K. 1992. Further Evidence on the Great Crash, the Oil-Price Shock, and the Unit-Root Hypothesis. Journal of Business $\sigma$ Economic Statistics, 10(3): 251-270. 


\section{APPENDIXES}

\section{Appendix A}
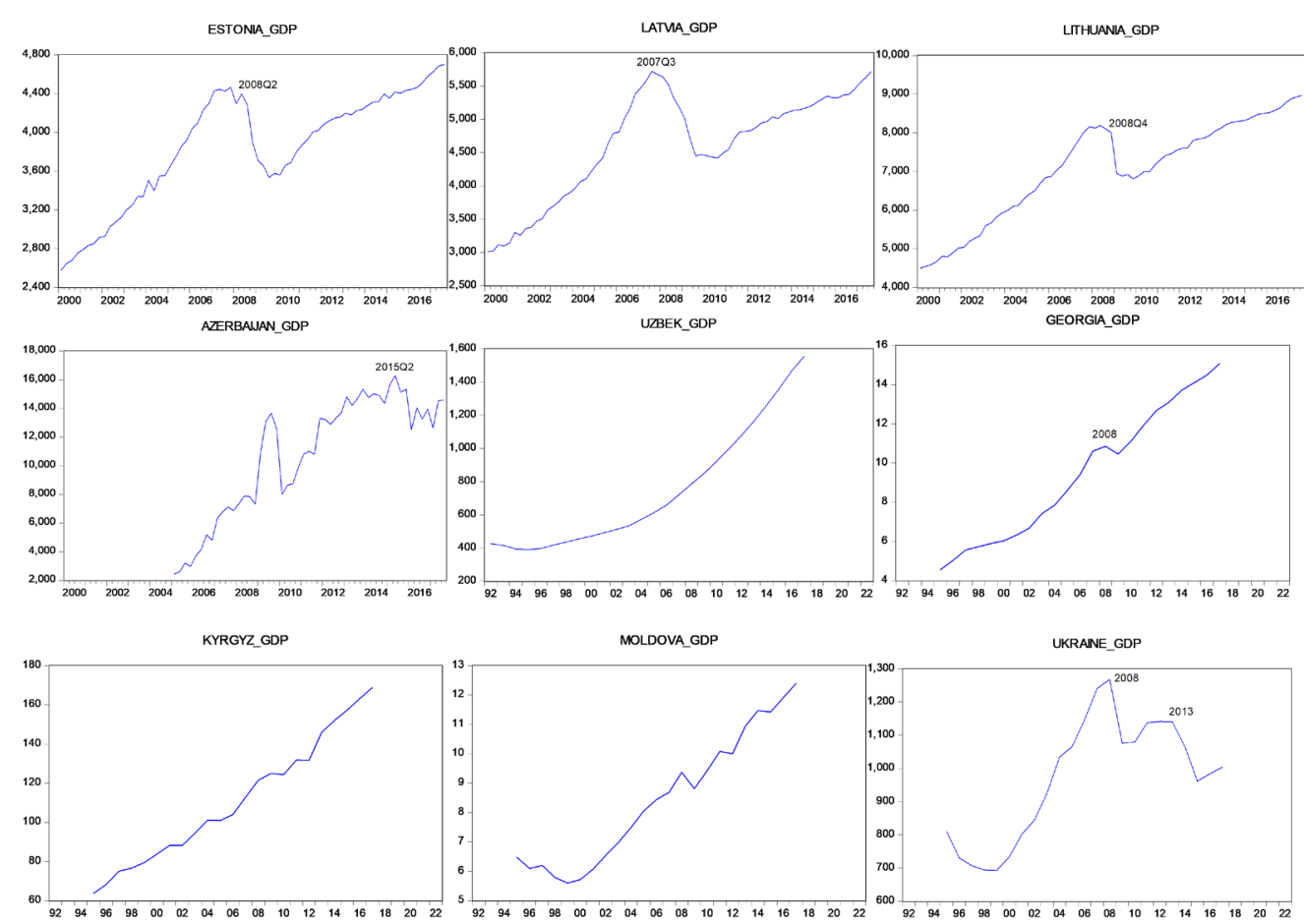

Al: Real and seasonal adjusted GDP
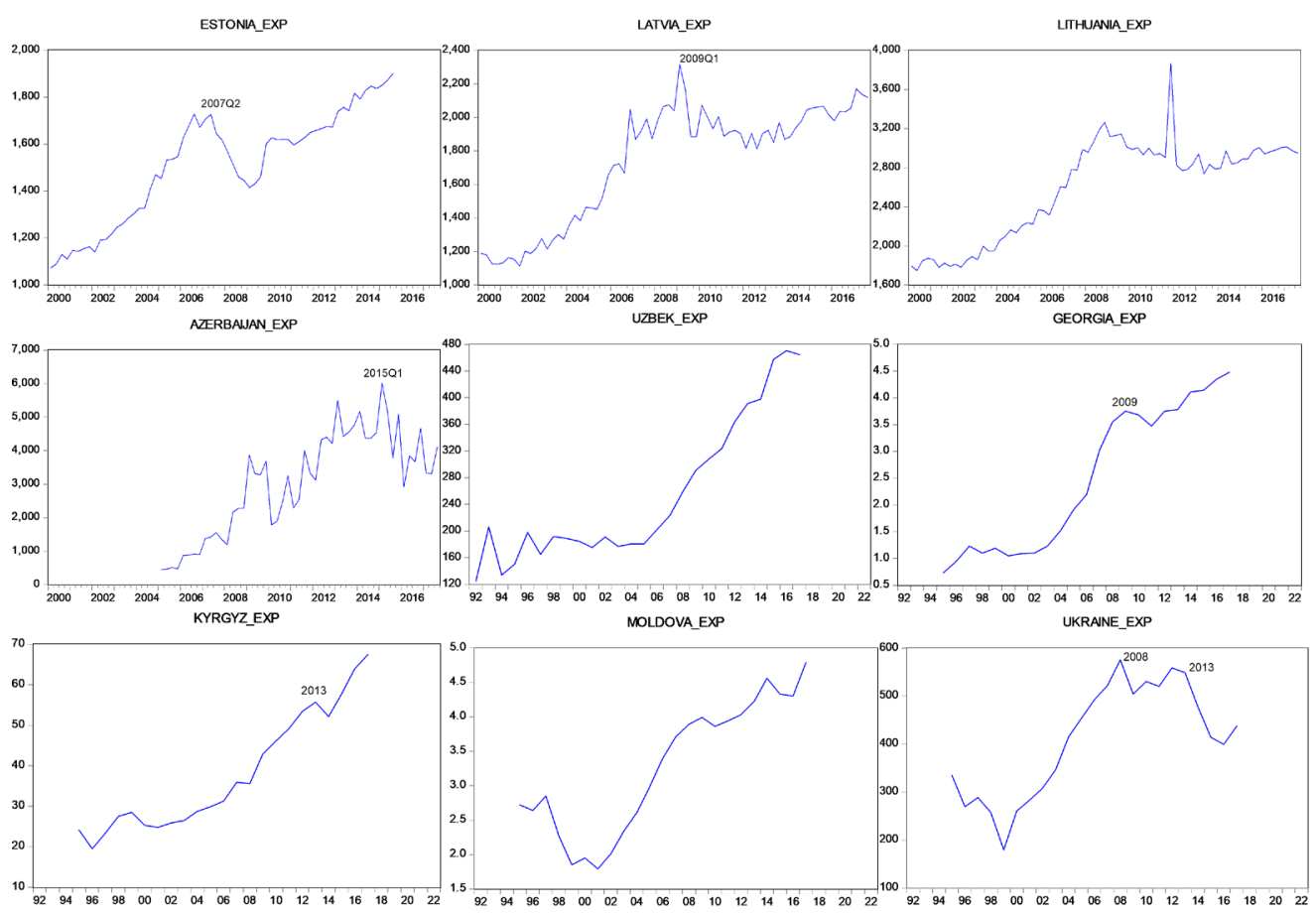

A2: Government expenditures 


\section{Appendix B}

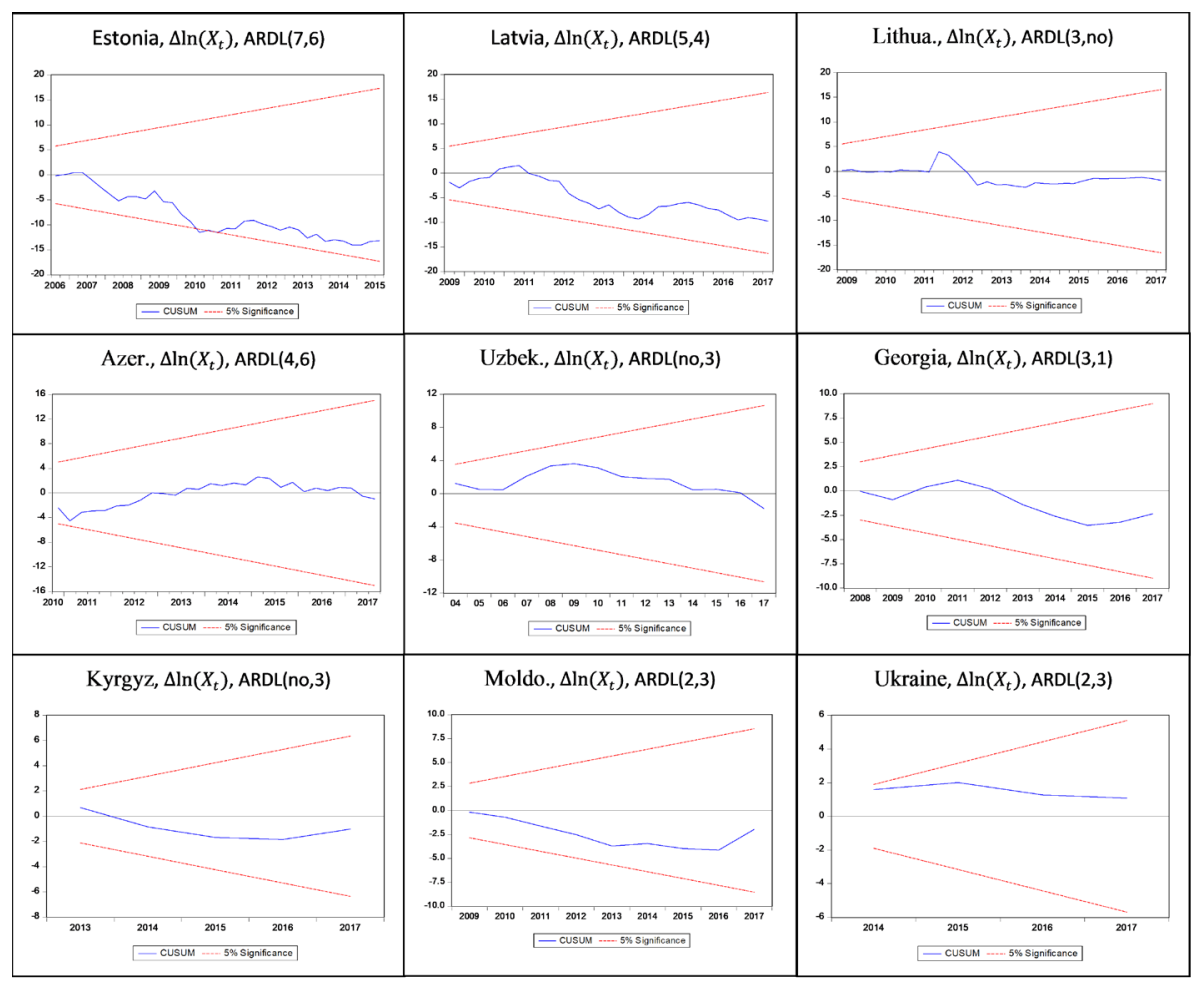

B1: CUSUM test for the stability analysis of the models in Tab. III

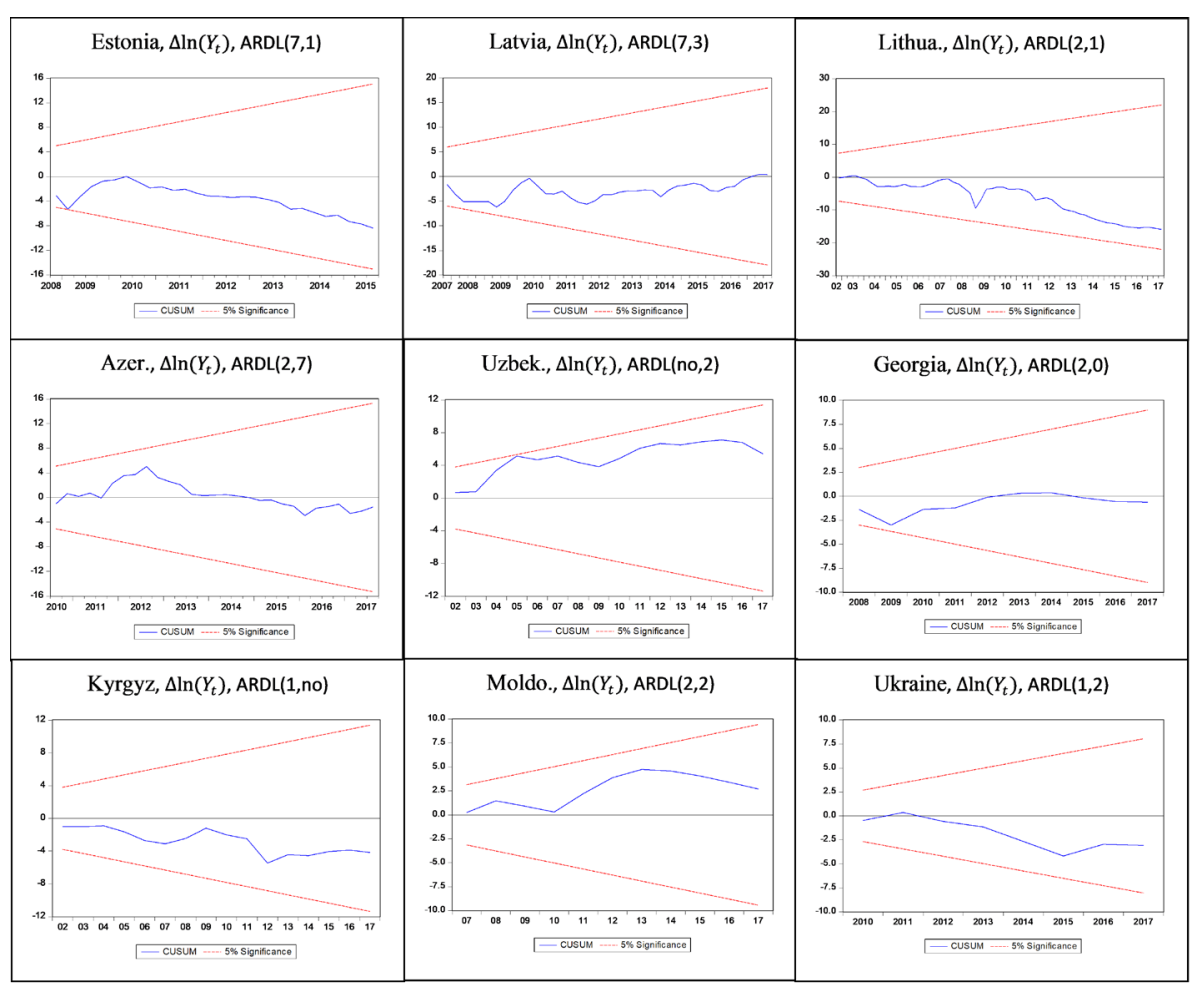

B2: CUSUM test for the stability analysis of the models in Tab.IV 